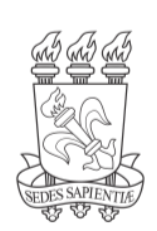

\title{
De Nietzsche a Husserl. Una consideración fenomenológica de la fantasía a la luz de la intuición trágica del mundo
}

\author{
From Nietzsche to Husserl. A phenomenological consideration of fantasy \\ in light of the world's tragic intuition
}

\author{
Fernando J. Barriga 1(i) \\ ' Universidad Alberto Hurtado, Departamento de Filosofía y Humanidades, Santiago, Chile
}

\section{RESUMO}

En el presente artículo desarrollaré una lectura en clave fenomenológica de El nacimiento de la tragedia de Nietzsche. Precisaré de algunas consideraciones en torno a la concepción de Fantasía propias de la fenomenología de Husserl. De esta manera, propondré una interpretación de la Fantasía a la luz de las consideraciones filológicas de Nietzsche, atendiendo a comprender la idea de Antigüedad a la luz de la perspectiva metafísica-estética sintetizada en su intuición trágica del mundo. ¿De qué modo la interpretación de la Antigüedad griega ofrece claves para una fenomenología de la fantasía? Este será el asunto central a tratar, con la intención de clarificar el modo de presentación del fenómeno del arte trágico, en tanto que expresión del mundo-de-la-vida de los griegos.

Palavras-chave: Fantasía (Phantasie); Presentación (Gegenwärtigung); Antigüedad (Antike); Intuición de mundo (Weltanschauung); Apariencia (Erscheinung); Mundo-de-la-vida (Lebenswelt)

\section{ABSTRACT}

In this paper I'm going to develop a phenomenological reading of The Birth of Tragedy of Nietzsche. I will specify some considerations around the conception of Phantasie in Husserl's phenomenology. In this way, I will propose an interpretation of Phantasie in the light of Nietzsche's philological considerations, in order to understand the idea of Antiquity in the light of metaphysics-aesthetics perspective synthesized in his world's tragic intuition. How does the interpretation of Greek Antiquity offer clues to a phenomenology of fantasy? This will be the central issue to be discussed, with the intention to clarify the way of presentation of the phenomenon of tragic art, in so far as expression of life-world of the Greeks.

Keywords: Fantasy; Presentation; Antiquity; World intuition; Appearance; Life-world 


\section{INTRODUCIÓN}

Los cursos de 1904/05 del filósofo alemán Edmund Husserl, que corresponden al tomo XXIII de Husserliana ${ }^{1}$, impulsan una indagación fenomenológica indispensable para dilucidar el estatuto filosófico de la fantasía (Phantasie). Atender a la Phantasie como un asunto central del análisis fenomenológico, supone inscribir el asunto en un campo de indagación más amplio y que conlleva una distinción fenomenológica preliminar de actos. Siguiendo esta idea, la fenomenología en su planteamiento programático inicial propone una distinción de actos intuitivos a partir de lo que Husserl denominará "carácter de acto" en tanto que "aprehensión"2. En este escenario, la fantasía es considerada en primer lugar como un "carácter de aprehensión de acto", que se distingue del acto perceptivo tanto en su modo de dirigirse al objeto intencional como en su contenido.

Siguiendo las consideraciones de Husserl en Phantasy, Image Consciousness and Memory en Hua XXIII, hay un elemento común en la fundación de ambos actos intuitivos en la Vergegenwärtigung o "presentificación" ${ }^{3}$. Es posible apreciar cierta inclinación teórica en Husserl por priorizar el acto perceptivo conforme a la identidad de la unidad del objeto intencional: la presentación, en estricto rigor, es un acto fundado en la percepción, o sea, en la conciencia (inmediata) del objeto como estando ahí-presente; ahora bien, la imaginación como modo de la fantasía cumple un papel relevante en la comprensión de dicho énfasis fenomenológico perceptivo. El correlato intencional perceptivo corresponde a los datos sensoriales presentes e internalizados en la corriente de la conciencia actual. Sin embargo, la hipótesis que planteo en este punto es que la Phantasie corresponde a una forma de la intuición, o bien, una forma necesaria de los actos intuitivos. En dicho modo del acto, se presenta una modificación del acto

\footnotetext{
1 Desde ahora: Hua XXIII.

2 HUSSERL, Investigaciones lógicas, II 6.

${ }^{3}$ HUSSERL, Husserliana XXIII, 109, 342. En algunos casos, traducido como "re-presentación" (Representation).
} 
intuitivo que se distingue tanto en su modo de dirigirse al objeto como en el contenido de dicho objeto intencional. Conforme a esta consideración, cabe señalar que Husserl reconoce cierto estatuto de realidad a la fantasía que resulta en cierto sentido problemático, ya que su carácter implica una cuasi-realidad. El modo de presentación de la fantasía es la "presentificación" (Vergegenwärtigung). Este tema será central para abordar lo que sigue a continuación.

En el presente artículo propongo una consideración fenomenológica de Die Geburt der Tragödie 4 , "El nacimiento de la tragedia", del filósofo alemán Friedrich Nietzsche. Para dicho propósito, me centraré primero en una consideración de GT en tanto que una "filología-fenomenológica" ${ }^{5}$ para precisar en qué sentido es posible afirmar del enfoque filológico nietzscheano un carácter fenomenológico. Por lo tanto, será necesario reflexionar en torno a ciertos aspectos de la fenomenología que inciden en la imagen de Antigüedad que Nietzsche propone en GT. Luego, me centraré en una consideración sobre la concepción de intuición (Anschauung) en Nietzsche a la luz del concepto de Phantasie planteado en su obra de 1872 dedicada a la tragedia griega. En este punto, sostengo que Nietzsche propone un modo de presentación de la Antigüedad, que se expresa en su descripción filológica de la Weltanschauung griega. Siguiendo a Nietzsche, esto es la representación de la esencia trágica de la existencia, "en el espíritu de la música", tal y como indica el título de su publicación original en 1872.

En síntesis, precisaré que el modo de presentación de la Antigüedad griega conlleva un entramado de actos de presentificación de naturalezas divergentes, pero necesarios en el entramado de la interpretación de la Antigüedad griega: por una parte, lo mentado es el modo de la fantasía griega mediante el análisis filológico riguroso de la tragedia como modelo artístico de los griegos; por otra parte, es también la representación (Vorstellung) fenomenológica que Nietzsche propone de la fantasía griega, y en mayor grado, de la fantasía como tal. Para esta consideración, precisaré de una lectura de la Weltanschauung trágica propuesta por Nietzsche a la luz del concepto

\footnotetext{
${ }^{4}$ Desde ahora: GT.

${ }^{5} \mathrm{BABICH}$, Nietzsche's Performative Phenomenology, 119.
} 
husserliano de Lebenswelt (Mundo de la vida). La tesis del presente artículo se entreteje entre dos aspectos de esta lectura fenomenológica de GT: (i) la tesis de que la fantasía griega está más próxima a la realidad, fundamentalmente en la época pre-platónica; (ii) que este modo de presentificación de la Antigüedad permite profundizar en las consideraciones fenomenológicas que Husserl propone sobre Phantasie. Por su parte, Nietzsche es la invitación a imaginar una posible fenomenología.

\section{Una aproximación fenomenológica al "método" filológico nietzscheano}

“[...] - pues sólo como fenómeno estético están justificados eternamente la existencia y el mundo..." ${ }^{\prime \prime}$

El mundo no es sino fenómeno estético y la existencia queda justificada eternamente según esta afirmación. A esto Nietzsche llamó <<justificación estética>> del Dasein, que en principio identifica existencia y mundo como "fenómeno estético"7. Esta es la piedra angular de la ästhetischen-Metaphysik", de la "metafísica-estética" que el joven filólogo alemán invoca en su primera obra publicada, El nacimiento de la tragedia en el espíritu de la música, cuyo título fue intencionalmente reformulado en la re-edición de 1886, que titula dicha publicación como El nacimiento de la tragedia o Grecia y el pesimismo. La "ciencia estética"9 que Nietzsche busca consagrar es una estética-filosófica, y por lo tanto, reivindica pero también excede el sentido del concepto de la escuela de los modernos, de Baumgarten a Winckelmann, quienes reconocían el estatuto cognoscitivo de la sensibilidad (Baumgarten) pero también el valor del arte griego como modelo estético de la Antigüedad (Winckelmann). Es una estética filosófica, en tanto que pretende una justificación metafísica de la existencia, pero a la luz de una reformulación de la propia metafísica, introduciendo categorías que remiten a experiencias propiamente estéticas y en estricto rigor artísticas. La pregunta ¿Qué es la

\footnotetext{
${ }^{6}$ NIETZSCHE, El nacimiento de la tragedia, 81; KGW, 1872, GT, 5.

7 Ídem.

${ }^{8} \mathrm{NIETZSCHE}$, El nacimiento de la tragedia, 76; KGW, 1872, GT, 5.

${ }^{9}$ NIETZSCHE, El nacimiento de la tragedia, 49; KGW, 1872, GT, 1.
} 
esencia? (metafísica) simultáneamente requiere contemplar la siguiente: ¿Cómo aparece el mundo? (estética). Según esta interacción entre esencia y apariencia, la metafísica estética se revela como una filosofía de la expresión, en tanto que la representación será la interacción entre esencia y apariencia, no en términos excluyentes ni resolutivos, sino como una constante amplificación potencia/ ${ }^{10}$ del ser.

Ahora bien, para precisar mejor la noción que Nietzsche pone en circulación en GT de "ciencia estética" resulta necesario atender a ciertas consideraciones que el pensador alemán propone unos años antes a dicha publicación; me refiero a su disertación inaugural a la cátedra de filología clásica de 1869, intitulada: “Homero y la filología clásica". En dicha disertación, en un contexto evidente y exclusivamente filológico, el joven filólogo nacido en Röcken formula una consideración crítica de la filología moderna, según la cual, para pensar en profundidad -esto es, rigurosamentela objetividad del concepto (Begriff) filológico de Antigüedad, es necesario precisar ciertos factores indispensables del análisis filológico, que aquí sintetizo en dos: (i) el modo en que se consolidan históricamente distintas escuelas de interpretación de las fuentes antiguas y (ii) la afirmación de una contradicción de instintos divergentes en la ciencia filológica en la conformación del concepto. En este punto, el planteamiento de una "ciencia estética" en 1872 presupone en gran medida su crítica "estética" de la filología de $1869^{11}$. El primer punto respecta principalmente a la creencia de la personalidad de Homero y el cómo de esta creencia: una singularidad que representa una voluntad colectiva versus la individualización concreta del autor de la llíada y la Odisea. Por motivos de extensión, me centraré a continuación en aclarar el segundo punto, que resulta clave para el presente artículo.

Nietzsche en 1869 reconoce que la Antigüedad es, por decirlo así, un concepto en disputa por su sentido genuino; una confrontación entre un modo intuitivo de presentar la Antigüedad y un modo lógico de tal presentación: arte (Kunst) y ciencia

\footnotetext{
${ }^{10}$ NIETZSCHE, El nacimiento de la tragedia, 56; KGW, 1872, GT, 2. Aquí aludo al concepto nietzscheano de "potencias artísticas" (künstlerische Mächte).

11 BARRIGA, El mundo como fenómeno estético, 9.
} 
(Wissenschaft) son las dos formas aparentemente irreconciliables en la época en que Nietzsche dicta esta disertación ${ }^{12}$, según lo cual se distinguen dos escuelas de interpretación: la poética (artística) y la filológica (científica). Lo innovador del ímpetu nietzscheano en esta crítica filológica, consiste en el intento de reconciliar ambas tendencias en un nuevo concepto de Antigüedad. Desde la perspectiva del joven catedrático de Basilea en 1869, resulta indispensable que la filología admita el componente artístico-intuitivo tan necesario como el componente científico-lógico. Además, resulta indispensable comprender la fundación de este estilo filológico como un modo de desvelar la herencia cristalizada del racionalismo filosófico moderno en el espíritu de la ciencia filológica de su época. Es en este sentido que GT, a este respecto, sea considerada como una obra filológica "polémica", en la medida que viene a proponer un nuevo concepto de Antigüedad a la luz de una justificación de una ciencia estética y una intuición filosófica del mundo. En este punto, Nietzsche es arriesgado al precipitar una consideración de la "intuición de la duplicidad de lo dionisíaco y lo apolíneo" en tanto que una certeza ${ }^{13}$; ahora bien, es justamente en esta afirmación de una intuición (Anschauung) de la esencia trágica en donde recae el énfasis del nuevo concepto de filosofía ${ }^{14}$.

En síntesis, Nietzsche formula una concepción "metafísica-estética" a partir de dos categorías que, en sentido filológico, son comprendidas a la luz de dos fenómenos de la esencia del arte trágico griego: lo dionisíaco y lo apolíneo. Respecto a esto último, es necesario aclarar que aquella "filología del futuro" (Zukunftsphilologie) ${ }^{15}$ que Nietzsche ya comienza a poner en circulación en 1872, no se reduce simplemente a una consideración "objetiva" en cuanto al método y el objeto de conocimiento filológico, sino que, simultáneamente ha de ser entendida como la presentación de una

\footnotetext{
12 NIETZSCHE, Homer und die klassische Philologie, 4.

${ }^{13}$ NIETZSCHE, El nacimiento de la tragedia, 49; KGW, 1872, GT, 1.

${ }^{14}$ Sin duda, esto anticipa de manera decisiva lo que en 1873 Nietzsche elaborará en sus apuntes compilados en La filosofía en la época trágica de los griegos, en donde se presume ya una consideración metafísica y estética del tipo de intuición originaria que Nietzsche entiende como apolíneo-dionisíaco.

${ }^{15}$ Concepto empleado por Wilamowitz-Möllendorf en 1872 en un tono irónico para referirse a GT.
} 
Weltanschauung: ciertamente la griega, pero también como signo de una nueva visión filosófica del mundo ${ }^{16}$.

De lo anterior se sigue que la noción de "metafísica-estética" resulta central en la comprensión de la intuición filosófica que caracteriza GT. Ahora bien, la tarea filosófica que plantea dicha obra, en términos generales, se anuncia ya al comienzo y consiste en el esclarecimiento intuitivo de la duplicidad artística de lo apolíneo y lo dionisíaco, principios que son estéticos, pero que en la reflexión de Nietzsche se circunscriben en el dominio metafísico. Para comprender dicha empresa, resulta central situar preliminarmente la duplicidad (Duplizität). Como ya se indicó previamente en la referencia a Colli (2010), los referentes culturales inscritos en la duplicidad remiten a las divinidades griegas del arte, puntualmente: Apolo y Dionysos. La duplicidad refiere a la configuración estética como tal a través de la interacción de ambos “instintos

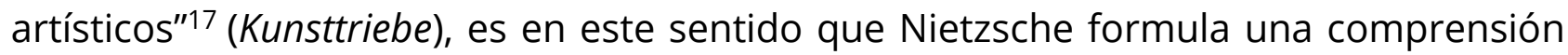
de la esencia del arte trágico en la afirmación de la oposición apolíneo-dionisíaco como tal. De esta manera, una primera aproximación al concepto de tragedia nos indica el carácter necesario (en sentido metafísico) de la propia duplicidad, que sólo se resuelve aparentemente $y$ en ciertas ocasiones ${ }^{18}$. Por lo tanto, la justificación estética de la existencia radica en la afirmación de la duplicidad en su carácter necesario: en este ámbito, lo apolíneo y lo dionisíaco no sólo indican instintos artísticos divergentes y originarios de la cultura griega, siendo cada uno expresión directa del instinto correspondiente, sino que vienen a proponer una comprensión filosófica de la constitución fenoménica de la existencia. El papel central de la intuición trágica de la existencia consiste en el esfuerzo por presentar como obra de arte, es decir, como

\footnotetext{
${ }^{16}$ COLLI, El nacimiento de la filosofía, 15. A este respecto, la tesis de este artículo consiste en proponer otro elemento: una fenomenología de la fantasía griega.

17 NIETZSCHE, El nacimiento de la tragedia, 57; KGW, 1872, GT, 2.

${ }^{18}$ La representación a la cual alude Nietzsche para ejemplificar este filosofema estético es la de la festividad e instinto primaveral relativo al culto dionisíaco griego; e incluso llega a sugerir una analogía entre el sentimiento (Empfindung) de alegría que surge de esta reconciliación metafísica entre Apolo y Dionysos con el sentimiento de unidad espiritual invocado en el "Himno de la Alegría" de Schiller (y musicalizado, vale decir, consagrado como obra de arte, por Beethoven).
} 
expresión de la interioridad griega, la incitación entre Erscheinung (Apariencia) y Ur-ein (Uno-originario) en tanto que un fenómeno originario (Urphänomen) que permanece irresuelto en la aprehensión de la existencia o, en sentido estricto, en la captación de la esencia trágica del Dasein. En este punto, se abre una pregunta crucial: ¿la comprensión del "fenómeno originario" del arte trágico es una interpretación estética de la Phýsis de los griegos antiguos? ¿Es posible la apariencia (estética) sin unidad (metafísica)? Estas interrogantes anticipan lo que será desarrollado principalmente en el §3 del presente artículo.

He precisado brevemente el modo en que Nietzsche relata la certeza de la esencia trágica en la tragedia griega. Sin embargo, es necesario ahora retomar el asunto inicial de este parágrafo. ¿Es posible trazar un método a partir de GT? ¿De qué manera aportaría a una consideración fenomenológica? Nietzsche afirma en el § 3 de GT, que lo que propone la obra es un "desmontaje" (Abtragen) de la "cultura apolínea"19. Este detalle es crucial para comprender la incidencia del fenómeno de lo dionisíaco en la cultura griega, pero también para entender el sentido de la pregunta por el método en la comprensión que Nietzsche realiza de la Antigüedad griega. Dicho Abtragen, no ha de ser tomado por una destrucción, ni menos una aniquilación de la cultura apolínea, sino más bien como una perspectiva arqueo-filosófica que parte con la interrogante de qué es y cómo llegó a ser lo apolíneo un signo característico de la cultura griega: Apolo es la divinidad de la Erscheinung y, en la consideración de Schopenhauer, es la idea misma del principio de razón y, en cuanto tal, es en un sentido metafórico el representante de la "bella superficie" ( $c f$. Nietzsche, KGW, 1871, NF, 7[91], [92]) del "tenebroso océano de la metafísica" (1873, NF, 26[6]). En este sentido, la duplicidad apolíneo-dionisíaco mienta un esquema ideal del objeto de estudio -en este caso, la "Antigüedad" - a través del cual Nietzsche muestra la representación adecuada a la esencia del arte trágico y, por añadidura, de la filosofía en la época trágica de los griegos; y sin embargo, lo que GT desarrolla es precisamente una comprensión filosófica de la intuición originaria

\footnotetext{
${ }^{19}$ NIETZSCHE, El nacimiento de la tragedia, 62; KGW, 1872, GT, 3.
} 
anticipada en la representación (Vorstellung) de la esencia trágica, al modo de una "imagen originaria"20 o "proto-imagen" (Urbild). La perspectiva arqueo-filosófica, por tanto, es aquella que interpreta (bedeutet) la objetividad filológica en vistas a describir una intuición filosófica del mundo.

La consideración de esta lectura metódica de la noción de Abtragen estaría fundamentada en ciertos criterios fenomenológicos que en la interpretación de GT se presentan como elementos discretos. Precisamente, los dos principales criterios que he considerado en este parágrafo son Gegenwärtigung y Bedeutung. Husserl realiza un análisis fenomenológico de la percepción según el cual, presentación e interpretación, son dos aspectos fundantes en el acto perceptivo. Dirá Husserl que la percepción, en un sentido amplio, es "interpretación de las sensaciones", en el sentido de aprehensión de la materia del acto intencional, o bien: que el carácter de aprehensión del acto es de algún modo interpretación perceptual. Gegenwärtigung corresponde, por decirlo así, a la estructura fenomenológica de presentación del objeto intencional fundado en acto perceptivo. En ambos casos, los componentes de la percepción aquí descritos remiten a Erscheinung, es decir, al carácter aparencial del fenómeno como tal. Lo que reluce en esta breve consideración sobre las lecciones de Husserl en Fantasía, Conciencia de imagen, Memoria (1904/05) es el énfasis en remarcar la Apariencia como la objetividad fenomenológica de toda presentación.

\section{Intuición y Representación}

El análisis husserliano de la intencionalidad desde el punto de vista de la esencia intuitiva del acto, ya desarrollado programáticamente en LU (1900/01) y re-articulado en sus cursos de 1904/05, propone una descripción de los momentos constitutivos del "acto intuitivo". Dicha descripción, por tanto, precisa de un esclarecimiento del modo de constitución fenomenológica del objeto intencional. La presentación se corresponde con el índice de la apariencia: en todo acto intuitivo algo aparece como tal, es decir, se

\footnotetext{
${ }^{20}$ NIETZSCHE, El nacimiento de la tragedia, 97; KGW, 1872, GT, 8.
} 
hace presente para una conciencia. Husserl añadirá que la representación del acto perceptivo ha de ser considerada como una proto-impresión o impresión originaria, que es la impresión desde la cual se desencadena una sucesión de modificaciones intuitivas posibles a partir de la presentación. Es en este sentido que la fenomenología husserliana, al menos en su planteamiento inicial, otorgue una prioridad a la percepción, en vistas a la plenitud del acto intuitivo. La plenitud aquí mentada está en conexión con el grado de presencia del objeto intencional. Ahora bien, el foco de atención sobre el análisis fenomenológico serán los modos de "presentificación" (Vergegenwärtigung) del fenómeno por intuición. Como ya he indicado, algunos pasajes de las lecciones de 1904/05 serán un referente central en esta sección.

A partir de lo anterior, atendamos a los conceptos indicados al inicio de esta sección: Intuición y Representación. La intuición en Nietzsche posee un papel central para esbozar un punto de vista originario de la filosofía. Ya se ha enfatizado en que la intuición que Nietzsche mienta es aquella certeza de la duplicidad de lo apolíneo y lo dionisíaco, que justifica como fenómeno estético la existencia y el mundo. Ahora bien, según lo indicado al final del parágrafo anterior, esta intuición originaria del arte trágico se expresa en una "imagen originaria" que simboliza el advenir de la voluntad griega en la imagen del "mundo de los dioses olímpicos". Nietzsche en GT sugiere entender esta imagen del mundo griego como la producción de un espejo transfigurador ${ }^{21}$ que el artista griego crea con motivo de justificar la existencia en su integridad exuberante, a la vez bella y sublime. De alguna manera, en esta interpretación subyace una afirmación del "impulso mítico"22 como vector inicial del pensar filosófico ${ }^{23}$, lo cual parece confirmar el siguiente fragmento póstumo: "Los grandes pensadores de la época trágica no reflexionan sobre otros fenómenos que aquellos que el arte igualmente considera"24, pero también siguiendo la indicación del NF 19[89], en donde

\footnotetext{
${ }^{21}$ NIETZSCHE, El nacimiento de la tragedia, 65; KGW, 1872, GT, 3.

${ }^{22}$ NIETZSCHE, Fragmentos póstumos, 38; KGW, NF 19[62].

${ }^{23}$ Tesis de la época trágica de la filosofía.

${ }^{24}$ NIETZSCHE, Fragmentos póstumos, 31; KGW, NF 3[24].
} 
Heráclito es tipificado como "Ilusión. Lo artístico en el filósofo. Arte"25. Es en virtud de estos antecedentes que es posible aclarar por qué, en referencia al "impulso mítico", cito:

Las horribles fábulas de la teogonía son un ejemplo del helenismo antiguo, [de] una fantasía acostumbrada a lo horrible. ¡De qué manera refleja a la vez una existencia terrenal! Una corriente desde la cual aquellos hombres se desplazan al ascetismo, a la catarsis (Orfeo, Pitágoras). ¡Una fantasía feroz como un tigre! ${ }^{26}$

Atendiendo ahora a una consideración de la Urbild de los dioses olímpicos, del cual se extrae la representación de la esencia del arte trágico como duplicidad de lo apolíneo y lo dionisíaco, veamos el modo en que se constituye la Erscheinung a partir del principio apolíneo del arte. En GT, Nietzsche señala dos modos de comprensión del fenómeno del arte trágico; por una parte, lo intuye desde la perspectiva natural del instinto artístico, para luego, por otra parte, discernir los fenómenos "estéticofisiológicos" en el artista humano, en quien se materializan los instintos artísticos naturales. En el estado de embriaguez (Rausch) se intuye el estado dionisíaco en donde la realidad es percibida como "realidad embriagada" ${ }^{27}$. En el estado dionisíaco, se expresa el sentido básico del Selbtsvergessen, del "olvido de si" 28 como condición de la unificación aparente con lo "Uno originario". A su vez, el estado apolíneo remite a la mesura de la fantasía griega. La sobriedad apolínea se traduce en la claridad de la "bella apariencia" ${ }^{29}$. En el estado apolíneo, dirá Nietzsche al alero de Schopenhauer, resplandece el principium individuationis ${ }^{30}$. Y es en este punto que precisaré de una aclaración del aspecto apolíneo del fenómeno del arte trágico. Si bien a la divinidad Apolo corresponde, en la interpretación de Nietzsche ${ }^{31}$, el dominio de la "bella

\footnotetext{
${ }^{25}$ NIETZSCHE, Fragmentos póstumos, 40; KGW, NF 19[89].

${ }^{26}$ NIETZSCHE, Kritische Gesamtausgabe Werke, NF 16[24]; traducción.

27 NIETZSCHE, El nacimiento de la tragedia, 56; KGW, 1872, GT, 2.

${ }^{28}$ NIETZSCHE, Kritische Gesamtausgabe Werke, NF 2[15]; traducción.

${ }^{29} \mathrm{NIETZSCHE}$, El nacimiento de la tragedia, 52; KGW, 1872, GT, 1.

${ }^{30}$ Forma espacio-temporal del aparecer de todo fenómeno.

${ }^{31}$ COLLI, Apolineo y dionisíaco, $\S \S 1$ - 3. Hago este hincapié para indicar que el estudio crítico de Giorgio Colli respecto a esta materia, suele indicar ciertas discrepancias conceptuales con el concepto nietzscheano de apolíneo.
}

Voluntas, Santa Maria, v.12, n.1, p. 01-27, jan/abril., 2021 
apariencia" asociada al mundo aparente de la claridad diurna ${ }^{32}$, también dirá que es necesario extender el dominio apolíneo a la apariencia de la "realidad onírica" (Traumwirklichkeit) e incluso al componente formal musical en la lírica. Cito: "Él, que es, según su raíz, <<el Resplandeciente>>, la divinidad de la luz, domina también la bella apariencia del mundo interno de la fantasía..." ${ }^{\prime 33}$. ¿De qué manera es posible extraer de lo apolíneo una consideración fenomenológica de la Erscheinung?

Si bien lo apolíneo siempre está en vistas a lo dionisíaco, es decir, a la esencia musical de la tragedia, a la música en tanto que "fuerza de la fantasía que domina la voluntad"34, es en la apariencia apolínea en donde se expresa lo dionisíaco. En otros términos, la música (aspecto dionisíaco) es el fenómeno originario del cual emergen las representaciones fenoménicas (aspecto apolíneo) en la tragedia. Es en este sentido, que la crítica que impulsa Nietzsche a la estética moderna revela que el fenómeno musical no es un simple acompañante o un mero ingrediente del $d r a m a^{35}$, sino que es su esencia o, al menos, el núcleo vivo de la tragedia griega. El drama, en estricto rigor, es decir, como objeto fenomenológicamente constituido, requiere -como veremos en la siguiente sección- de la interacción de las potenciales fuerzas actuantes en la tragedia: la fantasía y la acción ${ }^{36}$. Sugiero que, lo que Nietzsche plantea en los primeros parágrafos de GT respecto a la intuición de lo apolíneo, consiste en una presentificación de la realidad de la fantasía griega. La preeminencia (ontológica) de la Phantasie requiere una observación del cómo de lo apolíneo. Apolo es la apariencia resplandeciente, es decir, que yace en el claro de la luz (Phos), pero lo que impulsa constantemente a su representación es el fondo dionisíaco, la "terrible profundidad"37

\footnotetext{
32 Es decir, es la representación de las representaciones empíricas.

33 NIETZSCHE, El nacimiento de la tragedia, 52; KGW, 1872, GT, 1.

${ }^{34}$ NIETZSCHE, Kritische Gesamtausgabe Werke, NF 5[70]; traducción.

${ }^{35}$ De por qué Nietzsche se declarase como un anti-wagneriano. Como es sabido, Wagner solía enfatizar que en la tragedia, la música debía "acompañar" las acciones y sucesos del drama, de forma tal que se potencie el efecto patológico que la imagen (Bild) incita en el sentimiento.

${ }^{36} \mathrm{Y}$ en un sentido fenomenológico, el drama requiere de la unificación de la significación y la intuición. El drama, por tanto, es un efecto de la interacción entre música (fantasía) y acción.

${ }^{37}$ NIETZSCHE, Fragmentos póstumos, 33; KGW, NF 7[91].
} 
del "tenebroso océano de la metafísica"38: es el mar embravecido que remece el timón del navío de la individuación. Sin embargo, en su función simbólica, lo apolíneo es la apariencia que trasluce la realidad empírica en "imagen onírica" 39 (Traumbild). En síntesis, es posible complementar esta consideración con el siguiente fragmento póstumo:

Por lo tanto, en el origen (Ursprung) de la tragedia, sólo el coro es [lo] real en la orquesta, mientras que el mundo del escenario, los caracteres y sus actos, sólo se hizo visible como imágenes vivas, como figuras simuladas de la fantasía apolínea del coro. Ese proceso nocturno de la revelación de la visión que se extiende desde lo individual al coro[,] reaparece como lucha y victoria de Dionysos y se hace sensible ante los ojos del coro ${ }^{40}$.

Siguiendo lo anterior, propongo que el estudio filológico de la Antigüedad que emprende Nietzsche en su juventud, especialmente atendiendo al coro musical trágico de los griegos, propone una fenomenología del arte trágico, a la vez que una reducción de los supuestos metafísicos predominantes en los sistemas filosóficos racionalistas que tienden a subordinar la esencia del ser al valor lógico. En otras palabras, el quid fenomenológico de El nacimiento de la tragedia estriba en: (i) La creación de una imagen (Bild) de la Antigüedad -considerando como núcleo de la cultura griega el fenómeno del arte trágico, lo que sería el asunto filológico-filosófico por excelencia; (ii) En la elaboración de un concepto filosófico que colisiona con los presupuestos predominantes de la tradición metafísica Occidental, y en ese sentido, es posible leerla en clave de un cierto tipo de "reducción" fenomenológica de algunos presupuestos metafísicos predominantes en la definición del concepto filosófico de existencia.

Que la justificación (Gerechtigkeit) sea de carácter estético no es un detalle menor, si consideramos que la justificación como categoría moral, que posee un carácter prescriptivo en referencia al mundo, supone necesariamente el impulso estético. ¿Cuál es el argumento filológico para dicha justificación estética de la existencia y, en términos específicos, de la Antigüedad griega? En principio, podría suponerse lo

\footnotetext{
${ }^{38}$ NIETZSCHE, Fragmentos póstumos, 42; KGW, NF 26[6].

${ }^{39}$ NIETZSCHE, El nacimiento de la tragedia, 57; KGW, 1872, GT, 2.

40 NIETZSCHE, Kritische Gesamtausgabe Werke, NF 7[127]; traducción.
} 
14 | De Nietzsche a Husserl. Una consideración fenomenológica de la fantasía a la luz de la intuición trágica del mundo

siguiente: la obra de arte trágica, es decir, el coro musical trágico de los griegos, lo que Heidegger enfatiza traduciendo a Nietzsche con la noción de "fenómeno artístico"41, revela una esencia íntima de la existencia, que se expresa de manera ejemplar y auténtica en la cultura del mundo antiguo -dicho en términos fenomenológicos, el Lebenswelt de los griegos y de su culto al <<mundo de los dioses olímpicos>>42: en el arte trágico el griego ve el mundo y se contempla a sí mismo en él. ¿Cuál sería el argumento filosófico inicial propuesto en GT? Que en términos metafísicos, el arte está en condiciones tal y como la moral, o incluso en un sentido aún más esencial, de justificar la integridad de la existencia ${ }^{43}$ como multiplicidad pura. Por lo tanto, la filosofía podrá extraer del arte trágico un concepto de existencia que simultáneamente excede e inhabilita el sentido habitual del concepto lógico. Sin duda, la lógica como ciencia es una de las expresiones de la cultura griega, sin embargo, no es su significación esencial, sino el efecto del propio logos griego. Lo que aflora en El nacimiento de la tragedia, es la tragedia de ese mismo logos que la tradición moderna ha engendrado y cristalizado en su ideal de Razón (Vernunft). Luego, el arte trágico participa en la creación de un logos. Podría decirse que el logos "poético" 44 es la forma de la justificación estética de la existencia propuesta por Nietzsche. Así, por ejemplo, el destino de Edipo rey ${ }^{45}$, en

\footnotetext{
${ }^{41}$ HEIDEGGER, Nietzsche, 72.

42 Por ejemplo, la concepción de Destino que en la visión de mundo de los griegos revelaba la existencia humana siempre en tensión con el reino de los seres divinos.

${ }^{43}$ Esta consideración permite aclarar la relevancia del concepto nietzscheano de "metafísica-estética": el principio filosófico que rige la estética aquí mentada es el nexo necesario entre multiplicidad y unidad del ser. Por lo tanto, el adjetivo "estética" de la metafísica conlleva una fundamentación de una visión metafísica que difiere de aquella racionalista que pretende reducir la multiplicidad a la unidad formal. La filosofía de Nietzsche en este período, ha de ser entendida básicamente como una "filosofía del arte", en tanto que confronta los presupuestos metafísicos y lógicos predominantes en la tradición occidental.

${ }^{44}$ ARISTÓTELES, Poética, 1447a 17-29.

${ }^{45}$ Para esta breve consideración del logos poético en la interpretación de la justificación del fenómeno estético, me remito al texto introductorio de Nietzsche a "Sobre la historia de la tragedia griega" (1870), dedicado a un estudio preliminar de la tragedia de Sófocles. Aquí Nietzsche elabora un análisis crítico del concepto de tragedia a la luz de la comprensión moderna del modelo de la tragedia antigua. En dicho análisis, se esclarecen algunos conceptos considerados aquí, especialmente el de: "contradicción irreconciliable”, “Destino” y “justificación poética” (cf. Nietzsche, KGW, SS 1870, II 3). La pregunta lapidaria que formula Nietzsche a este respecto, se formula más o menos así: “¿Puede ser considerado correcto el concepto [moderno] de [lo] trágico, cuando es imposible ilustrar (erklären) la génesis (Entstehung) de la tragedia a partir de él?" (cf. 1870, II 3, p. 9; traducción). El problema estriba en la comprensión moral de
} 
efecto, revela que la acción moral no sólo es un producto de la determinación de la voluntad, sino que no está exenta del Destino, y que el destino en este caso irrumpe en su carácter necesario, es decir: el Destino sentencia al momento en que la acción pretende revertir su destinación; así, se comprueba la hipótesis trágica de que la Physis rige el logos, y que la fantasía en los griegos posee un carácter esencial en su concepción de mundo la cual se orienta, a su vez, por una imagen del mundo.

\section{Fantasía e imagen}

El concepto de fantasía que pretendo esbozar aquí asume la interpretación del concepto alemán Phantasie literalmente como fantasía y no, como suele indicarse, en tanto imaginación. La precisión terminológica implica una distinción de dos conceptos aparentemente intercambiables al traducirlos, los de „Phantasie und Einbildungskraft”, fantasía e imaginación. La propia traducción de Einbildungskraft requiere de una aclaración, puesto que la palabra imaginación requiere de mayor precisión conceptual. Ein-bildungs-kraft, podría decirse: [la imaginación es] una-fuerza-formadora. En un sentido amplio, Bildung remite a Bild-, que se traduce usualmente por imagen, o incluso fotografía. Por lo tanto, el concepto de formación es modificado aquí en su sentido antes expuesto, y es reconducido a un sentido de formación como formación-de-imagen. Einbildungskraft, por tanto, será una fuerza-imaginativa, o bien, una potencia de llevar a imagen. El problema conceptual entre fantasía e imaginación es que parecen remitir a la misma actividad por la cual un fenómeno "originario" (en el caso de la tragedia griega, el coro) es representado en una imagen (Bild). Esta imagen deberá ser comprendida como la intuición de una acción, en el caso específico de la tragedia griega. Pero la génesis del drama como componente escénico y per-formativo surge a partir de la proyección de imagen, que es una producción creadora de la fantasía. A la luz de GT y

\footnotetext{
la "justificación poética", en donde el valor de la tragedia recae sobre el juicio consciente del sufrimiento de Edipo y el sentimiento concomitante de juzgar como justo lo que el Destino (Schicksal) sentencia, ambos aspectos considerados sólo desde el efecto trágico en el observador del drama, desde una perspectiva del asunto que limita la tragedia a resolución moral de la contradicción (Wiederspruch).
} 
los escritos del período de 1869/73, nos percatamos que es el coro quien produce la imagen del drama. Es decir, que la música - como "fuerza de la fantasía" - en el coro, es el espíritu del cual emanan las representaciones de la apariencia apolínea de la tragedia. ¿Qué incidencia fenomenológica se desprende de esta consideración?

En principio, que la representación (Vorstellung) de la esencia del arte trágico, no se "presenta" (vorstellen) al modo perceptual cuyo criterio está, en parte, fundado en el índice pleno de la "apariencia perceptual” del fenómeno. La interpretación de Nietzsche en GT es fenomenológica, puesto que se propone "hacer visible" un fenómeno originario del Lebenswelt de los griegos. La claridad de la apariencia (Erscheinung) helénica se expresa simbólicamente en Apolo, representante -en términos de Nietzsche- de la "voluntad helénica"46. Lo apolíneo, como forma del arte griego, se traduce como un componente esencial del arte trágico: es la condición de todo aparecer como "bella apariencia"; pero en un sentido más prioritario, es lo que permite que sea aprehensible la sabiduría trágica de Dionysos a través de la "sabiduría de la apariencia"47 de Apolo. Lo dionisíaco no es intuido directamente, sino a través de diversos estados suscitados por la representación apolínea. Lo dionisíaco es ya el fenómeno originario del cual se desencadena el mundo de la multiplicidad fenoménica. La posible lectura fenomenológica de la comprensión filológica del arte griego, delimita un modo de “presentificación" de la esencia musical del arte trágico. El coro satírico, como imagen originaria (Urbild) apolínea del sufrimiento dionisíaco, es el "principio consciente" que expresa la tensión entre lo Uno-originario y la Apariencia. A través de la música, una palabra se capta como bella: en cierto sentido, este es el pathos del espectador griego en la perspectiva de Nietzsche. ¿En qué sentido se relacionan fantasía e imagen?

Husserl en LU demarca una distinción esencial entre tres formas del acto intencional atendiendo a la esencia intuitiva del acto. En otros términos, propone una distinción de los modos de constitución del objeto intencional. Ahora bien, siguiendo

\footnotetext{
${ }^{46}$ NIETZSCHE, El nacimiento de la tragedia, 64 - 65; KGW, 1872, GT, 3.

${ }^{47} \mathrm{NIETZSCHE}$, El nacimiento de la tragedia, 53; KGW, 1872, GT, 1.
} 
los aportes de los estudios sobre fenomenología de la presentación de imagen, resulta necesario remitir al tomo XXIII de Husserliana, en donde Husserl, en conexión a sus cursos de 1904/05, contempla una investigación de la presentación, cuyo foco de atención apunta a describir los modos de aparecer del fenómeno en lo que define como "presentificación" (Vergegenwärtigung; Re-presentation). El hilo conductor que permite comprender ambos modos de darse el objeto intencional dentro de un mismo análisis fenomenológico radica justamente en el grado de presencia del objeto intencional, lo que constituye un aspecto fundamental de la esencia intencional del acto. Dicho en términos descriptivos: según el grado de presencia, el acto experimenta una modificación, lo que permite delimitar una distinción de los modos de re-presentar ${ }^{48}$ según la experiencia fenoménica determinada. La conciencia, dirá Husserl, experimenta perceptivamente el mundo, pero también de manera simultánea está recordando eventos o cosas, imaginando mundos posibles, visualizando imágenes en sus diversas variaciones. Este factor indica una diversidad de formas de la re-presentación, que en este sentido, habría que entender como un traer-a-presencia. Es decir, que todas las experiencias basadas en la presentificación tienen un elemento en común con la presentación fundada en la experiencia perceptiva: en cierto modo, algo aparece. Ahora bien, la fenomenología de Husserl ha de entenderse en este respecto como una filosofía de la percepción, en tanto que sólo en el acto perceptivo el objeto se presenta "en persona"49 (Leibhaftig).

¿Qué es percepción? En sentido fenomenológico, la percepción posee ciertas características esenciales: “Como presentación [la percepción], es conciencia de su objeto como [estando] presente" 50 , lo que implica distinguir los componentes del proceso implicado en la percepción, a saber: "apariencia perceptual y creencia perceptual 'están siempre ahí como el fundamento de toda cosa"' ${ }^{51}$. Según esta indicación, la descripción fenomenológica distingue apariencia y creencia perceptiva

\footnotetext{
48 HUSSERL, Husserliana XXIII, XXX.

${ }^{49}$ HUSSERL, Husserliana XXIII, 601.

${ }^{50}$ HUSSERL, Husserliana XXIII, XXXiii; traducción.

51 Ídem.
} 
como componentes del acto perceptivo, pero más aún, afirma que ambos están ya dados a priori en la fundación de cada cosa. Sin embargo, estos aspectos no se limitan a la presentación (conciencia perceptiva del objeto intencional) sino que se extienden al dominio de los modos de "presentificación". Con esto parece anticipar el tratamiento de la actitud natural a la luz de la epochê fenomenológica de Ideas I (1913). Según esta última consideración, la percepción está fundada en una creencia: la existencia del objeto. Ahora bien, el concepto fenomenológico de existencia está fundado en la conjunción del acto judicativo y el acto perceptivo, o sea, en la conciencia de la identidad ${ }^{52}$ del objeto como estando-ahí-presente: apariencia y creencia se funden en la presencia del objeto de la intención perceptiva. Sin embargo, para Husserl, en la Vergegenwärtigung el criterio de la "presencia" experimenta una modificación, e incluso, en experiencias del recordar es posible remitir la representación imaginada a un ente presente actualmente, pero que no se presenta inmediatamente a la percepción. La Phantasie, que es una forma fundamental de la presentificación, posee cierta estructura fenomenológica que Husserl indica en tres afirmaciones: "como si fuera" (gleichsam), "como si" (als ob) y "quasi-" "53. Según lo cual, en la fantasía el modo del aparecer no remite a ninguna posición de existencia del objeto; por lo tanto, la presentación de la fantasía ha de ser considerada según los criterios indicados.

Atendamos ahora al NF, 5[70]: „Es ist die Kraft der Phantasie, die hier den Willen (in der Musik) beherrscht"54. Atendamos a la primera proposición: "Ella es la fuerza de la fantasía..." ¿Cuál es la fuerza misma a la cual Nietzsche se refiere? A aquella según la cual la fantasía domina la voluntad, a saber: la música de la tragedia griega. Entonces, la música es la fuerza de la fantasía en la cual la voluntad es retenida. ¿En qué sentido la música podría ser algo así como una fuerza? Probablemente en tanto que es lo que mueve a la fantasía en un sentido muy íntimo. La música, por lo tanto, es el motiv de la

\footnotetext{
52 Para comprender el sentido de "identidad" aquí empleado, remito a las consideraciones de Husserl sobre "unidad estática" y "unidad dinámica" del acto de conocimiento, expuestos en la "Sexta Investigación" de $L U$.

53 HUSSERL, Husserliana XXIII, xxxvii.

${ }^{54}$ NIETZSCHE, Kritische Gesamtausgabe Werke, NF 5[70]; traducción.
} 
fantasía. Luego, en otro fragmento, Nietzsche añade que la fantasía es una actividad, a saber: la de proyectar "imágenes vivas" 55 (lebenden Bilden). En efecto, Nietzsche señala que la fantasía es entendida como "fantasía de la voluntad"56 (Phantasie des Willens), en tanto que es una proyección de imágenes vivas. En el fenómeno de la tragedia griega, esta fantasía de la voluntad sería impulsada por una fuerza activa en la tragedia: el coro. El coro es lo que impulsa a que la voluntad proyecte imágenes, enfrentándola. La "fantasía de la voluntad" proyecta en imágenes lo que el fenómeno del drama realiza. La gestualidad escénica, en tanto que el componente expresivo del drama, exige de la voluntad el concepto (intelecto) y la imagen (fantasía): es en ese sentido que Nietzsche afirma que la tragedia, en tanto que obra de arte, es el producto de una fantasía moderada, es decir, cuya mesura restringe su desenfreno y, por lo tanto, que la tragedia no sería producto de una deformación de la fantasía. En el mismo fragmento 1[70], añade que la tragedia nace de un principio consciente. Este principio consciente lo interpreto como la interacción de intelecto y fantasía de la voluntad ${ }^{57}$. El coro interpreta un canto que el drama expone a través de acciones. El canto es la forma expresiva del drama, las acciones son insinuadas por una recitación coral; el canto es lo que sostiene la presentación del drama, en la música. De esta manera, el efecto trágico del drama consiste en el influjo que inflige en la voluntad de quien lo contempla, de forma tal que lo invita a reconocerse en el canto. Este reconocimiento, empero, si bien está fundado en un principio consciente, su presupuesto es el Selbstvergessen, el olvido de sí: que es la exigencia de trascendencia propia de la tragedia. Nietzsche parece mantenerse al margen de la reducción del drama al efecto moral de la consciencia, algo que en DW Ilama "estética socrática": para que una obra sea bella, debe ser buena. Luego, para que sea buena, debe ser consciente, que es una interpretación moral de la tragedia muy usual en su época. Sin embargo, al apelar a un "principio consciente", sólo lo aplica a una demarcación conceptual de la Phantasie del trágico griego, explicitando que la fantasía

\footnotetext{
${ }^{55}$ NIETZSCHE, Kritische Gesamtausgabe Werke, NF 1[70]; traducción.

${ }^{56}$ NIETZSCHE, Kritische Gesamtausgabe Werke, NF 2[11]; traducción.

${ }^{57}$ Es decir, requiere del sujeto cognoscente.
} 
no es meramente una deformación de la realidad, sino que, por el contrario, ella misma produce un mundo de imágenes vívidas y que, en cierto grado, éstas presentan una "realidad onírica"58: Traumwirklichkeit. Sin duda, aquí alude al principio apolíneo de la antigüedad griega.

Volviendo a las consideraciones de Nietzsche sobre fantasía e imagen, nos percatamos que el análisis filológico del arte trágico revela una concepción de la fantasía y la producción de imagen que delimita criterios que permiten reflexionar en torno al planteamiento de la Fenomenología de Husserl. El análisis filológicofenomenológico de Nietzsche, atendiendo al concepto de una "filología fenomenológica", permite esbozar una teoría de la fantasía que no se restringe al modo usual de definirla a partir del acto perceptivo que enfatiza en el aspecto visual aparencial del ente. El nacimiento de la tragedia ofrece un análisis fenomenológico de la fantasía a partir de una comprensión filológica de la esencia del arte trágico: la música -en un tono ciertamente schopenhaueriano- es la expresión inmediata de la voluntad helénica. En la música recae la fuerza de la fantasía a través de la cual la voluntad logra formar una imagen. El drama es la objetividad de la interacción entre música y apariencia, entendidos como aprehensiones de la fantasía. En este sentido, la presentación (Gegenwärtigung) del fenómeno, a partir de las consideraciones filológicas del arte trágico, ciertamente la encontramos en la imagen proyectada por la fantasía como Ver-gegenwärtigung, pero en un sentido más prioritario, como Urbild en el coro trágico: la simbólica del sátiro de los bosques acompañante de la divinidad Dionysos es crucial como "tipo" trágico para comprender la naturaleza dionisíaca expresiva del coro. En este sentido, el análisis del coro deviene una fenomenología de la música, considerada esta última principalmente como canto. El canto hace aparecer la imagen mesurada que permite estabilizar lo dionisíaco mediante lo apolíneo del arte; el coro transmite a través del canto la mediación entre lo divino y lo humano, que la fantasía

\footnotetext{
${ }^{58}$ NIETZSCHE, El nacimiento de la tragedia, 51; KGW, 1872, GT, 1.
} 
proyecta en imágenes: la apolínea imagen mesurada. ¿Cómo intuye Nietzsche la duplicidad conceptual apolíneo-dionisiaco?

Vemos que en El Nacimiento de la tragedia Nietzsche propone una descripción de lo apolíneo y lo dionisíaco en términos de una certeza de la intuición estética. Pero ya en 1871, en su ensayo $D W$, comprende que en lo dionisíaco se establece una Weltanschauung, que aquí traduzco como "intuición de mundo". Ahora bien, esta intuición de mundo Nietzsche la entiende a la luz de una comprensión de una determinada época de la cultura griega, que él Ilama "época trágica de los griegos", aludiendo principalmente a la situación de la filosofía en la época de los "sabios" preplatónicos. Por lo tanto, lo dionisíaco como intuición de mundo corresponde a una situación originaria de la filosofía en la Antigüedad griega.

La interacción antes indicada entre lo divino y lo humano adquiere la forma de la cosmogonía, según lo cual, la existencia es concebida desde la relación contemplativa del griego con el Kosmos. Es, en términos muy concretos, la época del mythos griego. Sin embargo, la perspectiva de Nietzsche sugiere que a los sabios de la época trágica habría que considerarlos como filósofos y no exclusivamente como precursores de la filosofía. De ahí que el filósofo alemán desarrollara un esbozo de una teoría de tipos filosóficos ${ }^{59}$ teniendo presente la siguiente reflexión: “¿Qué es el filósofo? ¿Qué tal si respondemos mirando a los antiguos griegos?" 60 Luego de dicha interrogación, Nietzsche propone una tipología de dichos griegos antiguos, y vemos que Anaximandro representa concretamente la "visión trágica del mundo", si bien, por ejemplo, Colli (2008) -siguiendo la ruta de Nietzsche- interpretará a Empédocles como el trágico en sentido pleno. Todo esto conlleva, a través de un análisis crítico de elementos historiográficos de la cultura griega, a la comprensión filosófica de una situación originaria, que en GT se sintetiza en la duplicidad de lo apolíneo y lo dionisíaco. Ahora bien, lo que sugiero en esta consideración es que el esquema apolíneo-dionisíaco

\footnotetext{
${ }^{59}$ NIETZSCHE, Fragmentos póstumos, 31; KGW, NF 3[84].

60 NIETZSCHE, Fragmentos póstumos, 39; KGW, NF 19[89].
} 
comprende la intelección de la Physis de los antiguos griegos. Detengámonos a continuación en el siguiente pasaje del §1 de GT:

[...] El hombre filosófico tiene incluso el presentimiento de que también por debajo de esta realidad en que nosotros vivimos y somos yace oculta una realidad del todo distinta, esto es, que también aquélla es una apariencia: y Schopenhauer llega a decir que el signo distintivo de la aptitud filosófica es ese don gracias al cual los seres humanos y todas las cosas se nos presentan a veces como meros fantasmas o imágenes oníricas ${ }^{61}$

¿Cómo se explicaría tal afirmación? Para responder, se deberá considerar el ímpetu heraclíteo de la filosofía de Nietzsche; en otras palabras, admitiendo lo que Colli (2008) indica, a saber, que la unidad del ser es imaginada como una "Esencialidad interior fragmentada"62, una unidad nouménica que se traduce en Polemos primordial, en tanto que un estado de diferenciación de esencias que colisionan en un "mundo de la vida" (Lebenswelt; life-world): es la afirmación de la necesaria pluralidad ${ }^{63}$ del ser y de la variación como un elemento intrínseco al devenir del Ser. Desde esta perspectiva, la Erscheinung no sólo posee una impronta estética, sino una relevancia de índole ontológica, en tanto que la Apariencia es la multiplicidad fenoménica del ser como tal, multiplicidad que no es contradictoria en esencia, sino que constitutiva de la unidad del ser. A esto Nietzsche alude al conceptualizar la visión trágica del mundo como sabiduría trágica, símbolo de Dionysos en la figura del Sátiro.

\section{CONSIDERACIONES FINALES}

"Philosophia facta est quae philologia fuit"64

He precisado una lectura en clave fenomenológica de Die Geburt der Tragödie, tomando en consideración elementos centrales de la fenomenología de la presentación que Husserl pone en circulación, con el propósito de contrastar el

\footnotetext{
${ }^{61}$ NIETZSCHE, El nacimiento de la tragedia, 51; KGW, 1872, GT, 1.

62 COLLI, La naturaleza ama esconderse, 171.

${ }^{63}$ COLLI, La naturaleza ama esconderse, 183.

${ }^{64}$ NIETZSCHE, Homer und die klassische Philologie.
} 
tratamiento husserliano de la Phatansie a la luz de la perspectiva filológica que Nietzsche delimita en su intuición trágica del mundo y en la determinación de un concepto de Antigüedad que, como se ha constatado, remite a una Artisten-Metaphysik fundada en la intuición de la duplicidad apolíneo-dionisíaco. A la luz de esto, he atendido a la fundamentación del método filológico nietzscheano, considerando su disertación de 1869 y su incidencia en la obra de 1872.

El asunto fenomenológico se desprende de una consideración "metafísicaestética" de la existencia y el mundo. He intentado precisar una clave de interpretación del modo de presentación que Nietzsche efectúa en su obra publicada en 1872. A esto he denominado como una "fenomenología de la fantasía", explicando la complejidad del asunto a la luz de un entramado que conlleva, por una parte, una comprensión metafísica-estética del cómo de la fantasía griega; pero por otra parte, una comprensión fenomenológica de la Phantasie como tal. En este punto, surge la siguiente pregunta: ¿No será acaso el concepto de Traumwirklichkeit el criterio diferencial de la Erscheinung que conceptualiza Nietzsche? ¿En qué sentido? Para Husserl, como veíamos en el parágrafo anterior, la fantasía es descrita a partir de tres afirmaciones relativas al carácter de aprehensión del acto: como si fuera, como si y quasi-. La realidad (Wirklichkeit) de la fantasía, en sentido husserliano, es una quasi-realidad, cuyo objeto es un como si fuera algo que aparece como si real. En este sentido, la fantasía se resiste a la presentación perceptiva y se revela como potencialidad creadora de representaciones imaginarias fundadas en actos no-posicionales. Sin embargo, al afirmar el carácter quasi- de dicha realidad, comprende que el concepto mismo de fantasía conlleva una descripción problemática de su realidad. Nietzsche, considerando la fantasía griega a través de una comprensión filológica de la Antigüedad, llega a la intuición de que en la duplicidad de lo apolíneo y lo dionisíaco, el arte griego expresó una afirmación de la existencia en su totalidad. Apolo, como divinidad de la luz, es símbolo de la realidad de la apariencia en su totalidad. La fantasía del griego, según la interpretación del NF 1[70], es proyección de imágenes vívidas, que Nietzsche ejemplifica en las figuras de los templos. Teniendo en consideración la claridad como un aspecto estético del aparecer 
de la fantasía, Nietzsche atribuye una realidad a la "imagen onírica simbólica"65 en tanto que una Traumwirklichkeit: a través de la fantasía, aparece la realidad como "apariencia de la apariencia"66.

La filología tal y como Nietzsche la concibe y "pone en escena" en El nacimiento de la tragedia, es una filología de la vida tal y como Giorgio Colli (2020) la comprende en sus apuntes iniciales de Apolíneo y dionisíaco. Como anotación final de su disertación de 1869, Nietzsche escribe, parafraseando e invirtiendo la sentencia de Séneca: $<<$ Philosophia facta est quae philologia fuit $>>$, es decir, que la filosofía de hecho es lo que la filología alguna vez fue. La visión filosófica de la época de juventud de Nietzsche explora la Antigüedad griega intentando captar la representación de la esencia trágica, a través de la fantasía. Es decir, la filosofía de Nietzsche juega a crear la verdad (Wahrheit) de la intuición dionisíaca del mundo. En este sentido, el símbolo de su visión filosófica ha de ser la "transfiguración" 67 (Verklärung). De haber una verdad -y nada nos ha indicado lo contrario - ha de ser en sentido trágico puesto que la sabiduría dionisíaca se asemeja, en esta consideración, al concepto Polemos de Heráclito "el Oscuro": la afirmación de la pluralidad del ser como "multiplicidad pura"68 o, en otras palabras, como el múltiple puro que se resiste a ser reducido a simple unidad y, sin embargo, es justamente el logos quien pone en relación las individualidades de la Polemos, otorgando unidad a las cosas del mundo. Una última consideración al respecto, nos lleva a tratar el concepto de Antigüedad a la luz del Lebenswelt fenomenológico.

Boehm (2013) señala que el Lebenswelt ha de ser considerado como un "sistema único de relatividades subjetivas" 69 y agrega además, que no es probable reducir dicho sistema de relatividades a un único fundamento subjetivo, racional y científico. Y es que en cierto sentido, al atender al fenómeno de la vida ¿es posible agotarlo a un

\footnotetext{
65 NIETZSCHE, El nacimiento de la tragedia, 76; KGW, 1872, GT, 5.

${ }^{66}$ NIETZSCHE, El nacimiento de la tragedia, 69; KGW, 1872, GT, 4.

${ }^{67}$ NIETZSCHE, El nacimiento de la tragedia, 66; KGW, 1872, GT, 3.

${ }^{68} \mathrm{COLLI}$, La naturaleza ama esconderse, 180.

${ }^{69}$ BOEHM, Husserl and Nietzsche, 14; traducción.
} 
fundamento racional? En "Husserl y Nietzsche" ${ }^{70}$, respecto al mundo-de-la-vida se demarcará una distinción a partir del modo en que cada uno de estos pensadores tiende a tratar el problema de la crisis de la racionalidad Occidental, o sea, el de la "racionalidad socrático-platónica"71.

Como se ha constatado en el presente artículo, en GT ya se anuncia cierta posición crítica respecto del "racionalismo socrático" en la inclusión de "[...] un tipo de 'reducción' de los supuestos y teorías tradicionales respecto de la historia de la forma trágica del arte" 72. La "metafísica de artista" (Artisten Metaphysik) propone una metafísica-estética de la duplicidad de lo apolíneo y lo dionisíaco, que he interpretado en términos de una fenomenología de la fantasía griega y que se extiende a una consideración filosófica de la Phantasie. La Antigüedad, desde esta perspectiva la he considerado a la luz de una Weltanschauung, una intuición de mundo del mundo-de-lavida de los griegos. Para esto he contemplado la siguiente interrogante: ¿Cómo aparece la Antigüedad a través de la imagen que GT presenta en la intuición trágica del mundo?

\section{REFERENCIAS BIBLIOGRÁFICAS}

ARISTÓTELES Poética. Trad. Alicia Villar. Madrid: Alianza Editorial, 2011.

BABICH, B. Nietzsche's Performative Phenomenology: Philology and Music. En: Boublil, É.; Daigle, Ch. (Eds.) Nietzsche and Phenomenology. Power, Life, Subjectivity: "Part II. Power and Expression". Bloomington: Indiana University Press, 2013.

BARRIGA, F. El mundo como fenómeno estético: la metafísica de artista de Nietzsche en cuanto innovadora ontología de mundo. Tesis de grado de Magíster. Santiago de Chile: Universidad Alberto Hurtado, 2020.

BOEHM, R. Husserl and Nietzsche. En: Boublil, É.; Daigle, Ch. (Eds.) Nietzsche and Phenomenology. Power, Life, Subjectivity: "Part I. Life and Intentionality". Bloomington: Indiana University Press, 2013.

\footnotetext{
${ }^{70}$ BOEHM, Husserl and Nietzsche, $14-15$.

71 ídem.

72 BABICH, Nietzsche's Performative Phenomenology, 122; traducción.
} 
COLLI, G. Primera parte. <La filología ya no está muerta>; Segunda parte. Escritos y apuntes preparatorios (1938 - 1940) (§§1 - 3). En: Colli, G. Apolíneo y dionisíaco [título original: Apollineo e dionisiaco]. Trad. Miguel Morey. Editorial Sexto Piso: Madrid, 2020.

COLLI, G. El nacimiento de la filosofía. Trad. Carlos Manzano. Buenos Aires: Tusquets Editores, 2010.

COLLI, G. VI. Heráclito; VII. Empédocles. En: Colli, G. La naturaleza ama esconderse [título original: Physis kryptesthai philei]. Trad. Miguel Morey. Madrid: Ediciones Siruela, 2008.

HEIDEGGER, M. Libro I. La voluntad de poder como arte (1936 - 1937): Nietzsche como pensador metafísico. In HEIDEGGER, M (Editorial Ariel). Heidegger, M. Nietzsche Trad. Juan Luis Vermal. Barcelona: Editorial Ariel, 2014. Pp. 17 - 20

HEIDEGGER, M. Las cinco proposiciones del arte. In HEIDEGGER, M (Editorial Ariel). Heidegger, M. Nietzsche. Trad. Juan Luis Vermal. Barcelona: Editorial Ariel, 2014. Pp. 72 - 80

HEIDEGGER, M. La embriaguez como estado estético. In HEIDEGGER, M (Editorial Ariel). Heidegger, M. Nietzsche. Trad. Juan Luis Vermal. Barcelona: Editorial Ariel, 2014. Pp. 93 - 106

HEIDEGGER, M. La provocativa discrepancia entre verdad y arte. In HEIDEGGER, M (Editorial Ariel). Heidegger, M. Nietzsche. Trad. Juan Luis Vermal. Barcelona: Editorial Ariel, 2014. Pp. $138-146$

HUSSERL, E. Translator's Introduction; Chapter 1. The Question of Phantasy Presentation in Contrast to Perceptual Presentation. En: Husserl, E. Phantasy, Image Consciousness, and Memory (1898 - 1925), Vol. 11 [título original: Phantasie, Bildbewußtsein, Erinnerung, Band 23]. Trad. John B. Brough. Washington, D.C: Springer, 2005.

HUSSERL, E. Sección Primera. Las intenciones y los cumplimientos objetivantes. El conocimiento como síntesis del cumplimiento y sus grados: Cap. 1-Intención significativa y cumplimiento significativo, pp. 605 - 629; Cap. 2-Caracterización indirecta de las intenciones objetivantes y de sus variedades esenciales por las diferencias en las síntesis de cumplimiento, pp. 633 - 640; Cap. 3-Para la fenomenología de los grados del conocimiento, pp. 645 - 669. En: Husserl, E. Investigaciones Lógicas 2 [título original: Logische Untersuchungen]. Versión de Manuel G. Morente; José Gaos. Madrid: Alianza Editorial, 1999.

MONTINARI, M. La época de Basilea (1869 - 1879)Trad. Fernando Barriga. In: Nietzsche. Eine Einführung Walter De Gruyter Verlag: Berlin, 1998. Pp. 57 - 59.

NIETZSCHE, F.; COLLI, G.; MONTINARI, M. (Eds.) Kritische Gesamtausgabe Werke und Briefe. Paolo D'lorio (2009) (Ed. digital). Berlin/New York: Walter De Gruyter Verlag, 1967.

NIETZSCHE, F.; COLLI, G.; MONTINARI, M. (Eds.) Vorlesungsaufzeichnungen (SS 1870 - SS 1871): "Zur Geschichte der griechischen Tragödie: Einleitung in die Tragödie des Sophocles. 20 
Vorlesungen [SS 1870]: Einleitung, pp. 7 - 10; §1. Die antike und die neuere Tagödie in Ansehung des Ursprungs, pp. 10 - 14; §2. Die Musik in der Tragödie. (der Dithyrambus), pp. 14 - 17". En: Nietzsche, F.; Colli, G.; Montinari, M. NIETZSCHE WERKE. Kritische Gesamtausgabe. Berlin/ New York: Walter de Gruyter Verlag, 1993.

NIETZSCHE, F. Homer un die klassische Philologie. Versión Kindle. Deutschland: Die Perfekte Bibliothek, 2015.

NIETZSCHE, F. El nacimiento de la tragedia [título original: Die Geburt der Tragödie aus dem Geiste der Musik]. Trad. Andrés Sánchez Pascual. Madrid: Alianza Editorial, 2012.

NIETZSCHE, F. Fragmentos póstumos. Una selección. Ed. Günther Wohlfart; Trad. Joaquín Chamorro. Madrid: Abada Editores, 2004.

WINCKELMANN, J. J. Reflexiones sobre la imitación de las obras griegas en la pintura y la escultura. Trad. Salvador Mas. México: FCE, 2008.

\section{Contribuição de autoria}

\section{1 - Fernando Javier Barriga Ortega}

Licenciado e Mestre em Filosofia

https://orcid.org/0000-0001-6308-6145•fj.barr92@gmail.com

Contribuição: Único autor

\section{Como citar este artigo}

BARRIGA, Fernando, J. De Nietzsche a Husserl. Una consideración fenomenológica de la fantasía a la luz de la intuición trágica del mundo. Voluntas Revista Internacional de Filosofia, Santa Maria, v. 12, n. 1 e02, 2021. DOI 10.5902/2179378664503. Disponível em: https://doi.org/10.5902/2179378664503. Acesso em: dia mês abreviado. ano. 